\title{
The Japanese Language and Character Particles, as Seen in Dialect: Character Particles and Sentence-Ending Particles
}

\author{
Kenji TOMOSADA \\ Professor Emeritus \\ Prefectural University of Hiroshima, Japan \\ tomsad1127@gmail.com
}

\begin{abstract}
The article deals with the following three views and concludes that (1) the phenomenon in which a word related to the identity of the speaker (a sentence-ending particle with its origins in the firstperson pronoun ["first-person sentence-ending particle" hereinafter]) appears after other sentence-ending particles may be observed in dialect; (2) the phenomenon in which a word related to the identity of the listener (a sentence-ending particle with its origins in the secondperson pronoun ["second-person sentence-ending particle" hereinafter]) appears after other sentence-ending particles also may be observed in dialect; (3) the phenomenon of occurrence of the first-person sentence-ending particle at the end of the sentence has a different nature than the phenomenon of occurrence of the second-person sentence-ending particle at the end of the sentence.
\end{abstract}

Keywords: sentence-ending particles; first-person sentence-ending particle; expressing his or her own view; second-person sentence-ending particle; a way of polite expression

\section{Povzetek}

Članek obravnava tri točke in zaključuje, da (1) je pojav, ob katerem se beseda, ki se nanaša na identiteto govorca (tj. končniški stavčni členek z izvorom v zaimku 1. osebe [spodaj kot 'stavčni členek v prvi osebi']), pojavi po kakšnem drugem stavčnem členku, opažen v narečjih; (2) je pojav, ob katerem se beseda, ki se nanaša na identiteto slušatelja (tj. končniški stavčni členek z izvorom v zaimku 2. osebe [spodaj kot 'stavčni členek $v$ drugi osebi']), pojavi po kakšnem drugem stavčnem členku, opažen v narečjih; (3) da je pojavnost zgoraj omenjenih dveh končniških stavčnih členkov različna.

Ključne besede: povedni zaključni členki; stavčni členek za prvo osebo; izražanje osebnega mnenja; stavčni členek za drugo osebo; izrazi spoštljivosti 


\section{Introduction}

This paper examines the relationship between character particles as proposed in character studies and sentence-ending particles in dialects, considered to have developed from personal expressions.

Sadanobu (2005, p. 118) defines character particles as "particles that express the character one wants to convey." He provides the following example (hereinafter, the author has underlined the relevant part of each sentence).

O-hisashi-buri desu. Kuri de gozaimasu puu.

"It's been a long time. I'm sorry for not keeping in touch puu."

He explains that puu, as used in the above example, "seems to be used to establish a noncombative, easy-going character" (Sadanobu, 2005, p. 120).

Sadanobu $(2007$, p. 37) identifies the following three points concerning the conditions under which character particles may appear in a sentence to give "a fitting end to the sentence":

1. they are relatively less likely to appear in inverted sentences;

2. they are positioned even later than sentence-final particles;

3. they are relatively less likely to appear at the end of a clause within a sentence.

Sentence-ending particles were proposed by Yoichi Fujiwara in a study of dialects. Fujiwara re-examined the particles usually called sentence-final particles in the light of the importance to Japanese expression at the end of the sentence, calling them "sentence-ending particles." The study attracted attention for its view that such sentence-ending particles have originally come from personal expressions, pointing out that a wa at the end of a sentence originally was a word referring to the speaker (watashi), indicating that he or she was expressing his or her own view. Fujiwara (1986, p. 211) gives examples including:

Shiran wai. (I dunno.)

In Kyushu dialect, this would be:

Shirimasshen bai.

In these sentences, wai and bai are in fact first-person pronouns. The wa used in an expression such as lyada wa. ("Yuck!") also can be considered a first-person pronoun, since it belongs to the same family as wai.

Similarly, while expressing some doubt as to whether the particle is in fact in the first person, Fujiwara $(1986$, p. 431) also cites the following sentence from a dialect in Ishikawa Prefecture:

(1) Sonna mon kisesasshanna wa-.

"Don't make me wear something like that!" 
He says of this example:

'Perhaps this use of wa- to express one's own opinion is, after all, a first-person wa sentence-ending particle. Other uses of $w a$, such as its usefulness in expressing commands, also may have developed naturally from this use of $w a . '$

Fujiwara (1986, p. 431)

Fujiwara (1986, p. 211) rejects the theory on the origin from the binding particle ha (pronounced like wa) as follows:

'I would like to point out one doubt about the theory on ha. Ha is affixed to substantives and secondary substantives. It often is treated as an indicator of the subject. Generally speaking, particles with such a function stress what follows.

$W a$ as used in cases such as lyada wa indicates something said with intensity. Its true nature (functional value) is this intensity of the expression, the opposite of stressing what follows. Perhaps ultimately wa comes from the first person.'

The following example is from a dialect on the Matsushima Coast in Miyagi Prefecture.

(2) O shin1ko ne-su kaךwa

"Don't you have any oshinko?"

(The indication of accents here differs from Fujiwara's.

Fujiwara (1994, p. 238) argues that the tone of the sentence as well wa give a strong impression that the sentence has reached its conclusion, so that wa is unlikely to have come from ha since the former "is distinguished by the way it does not put any kind of stress on what is to come next."

In this way, the part of speech appearing at the end of a sentence in standard Japanese has traditionally been considered a sentence-final particle, but today character studies make it clear that a word related to the identity of the speaker (a character particle) may appear even after the sentence-final particle. At the same time, the phenomenon in which a word related to the identity of the speaker (a sentence-ending particle with its origins in the first-person pronoun ["first-person sentence-ending particle", hereinafter]) and appears after other sentence-ending particles may be observed in dialects as well, and Sadanobu suggests a parallelism between the character particle and this first-person sentence-ending particle. Accordingly, this paper will begin with a consideration of how this first-person sentence-ending particle appears in dialects.

The phenomenon in which a word related to the identity of the listener (a sentence-ending particle with its origins in the second-person pronoun ["secondperson sentence-ending particle", hereinafter]) appears after other sentence-ending particles also may be observed in dialects. 
(3) O-shaberi bakari shimashite na-ta.

"You sure did talk a lot"; Kumamoto Prefecture

NHK Zenkoku Hogen Shiryo

Here na-ta is a compound of na- and anata ("you"). If we understand standard Japanese as permitting only a first-person particle to appear after the sentence-final particle, then it is conceivable that the phenomenon in which a first-person particle occurs positioned after the sentence-final particle, and the phenomenon in which a second-person particle occurs positioned after the sentence-final particle could differ fundamentally in their nature. If both are homogeneous, then it is hard to conceive that only one of them would occur (the phenomenon of occurrence of the firstperson particle), while the other one (the phenomenon of occurrence of the secondperson particle) would not. Accordingly, as our second point, we will consider the ways in which the second-person sentence-ending particle appears in dialects.

Our third point will involve investigation of the distribution and usage of these phenomena and we will point out that the phenomenon of occurrence of the firstperson sentence-ending particle at the end of the sentence in fact has a different nature than the phenomenon of occurrence of the second-person sentence-ending particle at the end of the sentence.

\section{Usage of the first-person sentence-ending particle}

First, let's look at some examples considering the distinctiveness of dialect in which such particles are positioned at the end of the sentence.

(4) Do-ra hi ga heran uchi modoimoso wai.

"Whatever the case, let's return before the sun goes down";

Kagoshima Prefecture

(5) Arigato gozairimashite wai.

"Thank you very much";

Ishikawa Prefecture

(6) Unara ma-yokowasshai. Orya mo- inuru bai.

"Well, good night. I'm going home too";

Saga Prefecture

All three examples above are from NHK Zenkoku Hogen Shiryo.

(7) Honai i-mawaraidemo iku ware.

OK, I've heard enough. I'll go"; said by a 16-year-old younger brother to

his 23-year old elder sister;

Tokushima Prefecture

(From Fujiwara, 1986, p. 452)

(8) Agekkara wa.

"Here you go." 
(9) Nagete kunai wa. ("Throw it!")

(All of the above examples are from the southeastern area of the Tohoku dialect zone (Fujiwara, 1969, p. 205))

While there also are examples of ore ("I") being positioned at the end of a sentence, it might be difficult to consider these to be examples of sentence-ending particles.

(10) Cho-kite cho-chitemo- muridanbe ore. "I don't think I can make it today."

(From NHK Zenkoku Hogen Shiryo, Tochigi Prefecture)

It is apparent that many cases show compound sentence-final particles in which a first-person sentence-ending particle is combined with some other sentence-ending particle, such as:

Wai: wai na, wai no, wai ne, wai ya, etc.

Wa: wan a, wa no-, wa no, wa ne, wa yo, etc.

Bai: bai ta, ban ta, ba mai, etc.

While wai and wa above form compound sentence-final particles when suffixed with $n a, n o, n e, y o$, or ya, the ta, nta, and mai suffixed to bai are variants of the secondperson pronouns anta and omai.

Next, let's look at the words other than first-person particles positioned after the sentence-ending particle. Fujiwara (1969, p. 213) states that while a compound form bai $+X$ is possible, a compound sentence-ending particle $X+b a i$ is not.

However, Fujiwara (1997, p. 484) also cites the following example from a dialect in Nagasaki Prefecture.

(11) Sa- oremo sore shiran tobai.

"Gee, I don't know either."

Also, the NHK Zenkoku Hogen Shiryo includes the following example from Fukuoka Prefecture.

(12) $\mathrm{m}^{1}$ Batten miaidakea sake dashimasshen nabai.

Na-miaintokya-sake dashimasshen bai.

"But don't serve sake at a meeting with a view toward marriage.

Remember, don't serve sake at a meeting with a view toward marriage."

Does not this appear to be a case of $X+$ bai? In addition to this one, examples such as the following can also be seen in the NHK Zenkoku Hogen Shiryo:

1 'm' for male. 
(13) $\mathrm{f}^{2}$ Karaimo hottatoba chittobakkae yaro-kananta.

"I'd like to give you a little souvenir.

How about taking some of the yams we've dug up?"

(14) m Un karaimonara itcho- moro-te ikokanobai.

"Yes, I'd love to take a sweet potato with me"; Saga Prefecture

Furthermore, although it does not include bai, the following example also fits the pattern.

(15) Yanka kimonna itchomo motajattatoai.

"I didn't even have a single long kimono"

(NHK Zenkoku Hogen Shiryo; Kumamoto Prefecture)

There also are examples of a first-person sentence-ending particle positioned after another sentence-ending particle, as in this one from the dialect on the Matsushima coast of Miyagi Prefecture in Fujiwara (1994, p. 238).

(16) Oshinko ne-su kawa.

"Don't you have any oshinko?"

Sadanobu (1986) also points out that wa and wai may appear after consecutive sentences, as in the following example.

(16) Achi-na-. Honni yaren wa.

"It's so hot. I truly can't stand it"; Okayama Prefecture

Among the three points regarding the conditions under which character particles are likely to occur, the tendency to be relatively less likely to appear in inverted sentences can be said to wrok for first-person sentence-ending particles as well, and they also are relatively less likely to appear at the end of a clause within a sentence.

Sadanobu (2007, p. 46) describes first-person sentence-ending particles and character particles in the following way.

'Perhaps a case of a word such as gohon ("ahem"), an extreme expression of the character of the speaker's utterance, at a position at the end of the sentence where it is grammatically easy to place a watashi expression may be considered to be a character particle.'

Regarding the distribution of wai and wa, Fujiwara (1969, pp. 205-207) says:

'In general, people in the western half of Japan probably can be said to use "wai" widely. ... From an overview of the distribution of wa we can see that, in contrast to wai, it is distributed more in the eastern part of the country.

\footnotetext{
2 ' $f$ ' for female.
} 
However, although their distribution is largely split regionally, it is apparent that the first-person particles are used nationwide.'

\section{Usage of the second-person sentence-ending particle}

Now let's look at some examples where second-person particles are positioned the end of a sentence. There are two usages, namely the a-ta and the nonta ("you"), in combination with suffix elements.

(17) Konyawa a-ta.

"Good evening"; Kumamoto Prefecture

(18) A- ohayo- a-ta.

"Oh, good morning you."; Kumamoto Prefecture

(19) f I-e-a-ta kotchikoso gobure-shi mashite

"No, you my fault."

(20) m So-asakarubatten kya-yo-kana- $\underline{a-t a . ~}$

Kumamoto Prefecture

(21) Mo- sunde shimo-ta kotsujara nta.

"That's all in the past"; Oita Prefecture

(22) O-shaberi bakari shimashite na-ta.

"You sure did talk a lot"; Kumamoto Prefecture

(23) Sanju-guraini narimasuga nonta.

"He's about 30 years old"; Yamaguchi Prefecture

Na-ta probably comes from na- + anata, while nonta probably comes from no- + anata.

There are various ways in which a second-person sentence-ending particle can become a suffix element in a compound form:

$\begin{array}{lllll}\text { na-anta } & \text { no-anta } & \text { ne-ta } & \text { kaia-ta } & \\ \text { na-ata } & \text { no-ata } & \text { kaita } & & \\ \text { na-nta } & \text { no-an } & \text { kanta } & & \\ \text { nanta } & \text { no-nata } & \text { taita } & & \\ \text { naeta } & \text { no-nta } & \text { tanta } & & \\ \text { na-ta } & \text { nonta } & \text { banta } & & \\ \text { nata } & \text { noita } & \text { no-ta } & & \\ \text { namai } & \text { no-mai } & \text { nomai } & \text { kamai bamai }\end{array}$

Each of the above is a case of suffixing by a second-person particle. Fujiwara (1969, pp. 481-483) also describes a case of anta + na-. 
(24) Atsui antana-.

"It's hot you-"

(Buzen)

(25) Mukashi ha tanokusa wo shihen torimashitagaantana-

"We used to pull out weeds in rice field four times you-"

(Minamikawachi-gun, Osaka Prefecture)

Second-person particles also are used as interjections.

(26) m A-ma- mai omaemo mai rakuna mijan mai buraburashitorya e-njashino-

"Ah, well, you should dress casually too. Take it easy";

from the NHK Zenkoku Hogen Shiryo; Mie Prefecture

\section{Distribution of first-person sentence-ending particles and second-person sentence-ending particles}

Fujiwara (1986, p. 497) notes that

'In sum, first-person particles such as "wa" and "wai" are used widely in dialect across the country, ... while second-person particles are less widely used outside some accents in Kyushu dialect.'

If, as Fujiwara argues, first-person particles are used by 'the speaker to make a point, expressing his or her own point of view to the listener', then they would appear to be unrelated to regional characteristics.

On the other hand, the use of second-person particles is thought to be representative for Kyushu dialect. However, Fujiwara (1969, p. 196) notes that the use of $a$-ta in the following example gives the sentence a medium or higher level of politeness:

(27) Konyawa a-ta.

"Good evening"; Kyushu

In this way, could not the use of a second-person particle be taken as being dependent on the degree of politeness of the expression? If so, there would only be one method of polite expression in certain regions centered in the Kyushu dialect, and Fujiwara (1969, p. 497) describes it as follows:

'From the general possibility of use of statements such as ne-anata, it is conceivable that second-person sentence-ending particles could be more widely used in dialect. However, that is not in fact the case. Perhaps this implies that people prefer to use sentence-ending particles belonging to the watashi family when expressing themselves to others in sentence form. (Perhaps use of watashi sentence-ending particles is a natural development.) 
However, Fujiwara (1986, p. 379) also says the following about forming sentenceending particles from personal pronouns:

'We can understand the formation of sentence-ending particles from secondperson personal pronouns as being the most natural occurrence since those words are used to call others. But why form sentence-ending particles from firstperson personal pronouns? If we think about it, this too is natural. The speaker is attempting to express him or herself. He or she is attempting to present his or her own point of view to the other party.

Is it not the case that even when using a second-person personal pronoun, ultimately the speaker is calling the other party with anata or a similar word, expressing his or her own (the speaker's) point of view?'

\section{Conclusion}

From the above we could conclude that the sentence-ending particles $w a$, wai, and bai, which have their origins in first-person pronouns but differ in regions of their distribution, are used across Japan when a speaker attempts to present his or her own point of view to the listener. Also, the use of such sentence-ending particles shows some similarities with the way a character particle embodies the character the speaker wants to convey, and that both may appear positioned after the sentencefinal particle (another sentence-ending particle). In this way, we have identified the relationship between these two types of particles.

At the same time, the sentence-ending particles with origins in second-person pronouns, observed in dialects, differ in their nature in that they are a way of polite expression used in regions centered on Kyushu. Still, as Fujiwara (1986, p. 379) says, 'ultimately the speaker is calling the other party with anata or a similar word, expressing his or her own (the speaker's) point of view'.

\section{References}

Kambe, H. (1975). Oki hogen no bunpyogenjo no 'wa' rui bunmatsushi ('Wa'-type sentence-ending particles in sentence expression in Oki dialect), Kokubun gakuko, no. 66.

Sadanobu, T. (2005). Sasayaku koibito, rikimu repota: kuchi no naka no bunka (Whispering lovers, boastful reporters: the culture of speech), Iwanami Shoten.

Sadanobu, T. (2007). Kyarajoshi ga arawareru kankyo (Conditions under which character particles appear), in Yakuwarigokenkyu no chihei, Kurosio Publishers.

Sadanobu, T. (2011). Kyarakuta ha bunpo wo doko made kaeru ka (To what degree do characters change grammar), in Yakuwarigokenkyu no chihei, Kurosio Publishers. 
Sadanobu, T. (2012). Nihongo shakai no nozoki kyarakuri (A look at the social conditions of the Japanese language through characters), Sanseido.

Sato, T. (1977). Hogen bunmatsushi no kijutu: Mie-ken Suzuka-shi Ejima-cho hogen no bunmatsushi (An account of sentence-ending particles in dialect: sentence-ending particles in the dialect of Ejima-cho, Suzuka, Mie Prefecture), in Hogen kenkyu sosho, vol. 7, Miyaishoten.

Tomosada, K. (1986). Okayama-ken hogen no kenkyu: bunmatsushi wa/wai nit suite (A study of Okayama Prefecture dialect: the sentence-ending particles wa and wai), in Kokugo hogen kenkyu, no. 3.

Noma, J. (2011). Osaka hogen no bunmatsushi de to wa (The sentence-ending particles de and wa in Osaka dialect), Osaka shakaigengogaku kenkyu noto 9.

Fujiwara, Y. (1969). Nihongo hogen bunpo no sekai (The world of grammar in Japanese dialect), Hanawashobo.

Fujiwara, Y. (1986). Hogen bunmatsushi (bunmatsujoshi) no kenkyu (ge) (A study of sentence-ending particles in dialect [vol. 2]), Shunyodo Publishing.

Fujiwara, Y. (1994). Bunpogaku (Grammar studies), Musashinoshoin.

Fujiwara, Y. (1997). Nihongo hogen jisho: geken (Dictionary of Japanese dialect [vol. 3]), Tokyodo. 